\title{
Safety provision at the presence of arc flash hazard in the high voltage equipment
}

\author{
Marinela Yordanova ${ }^{1}$ \\ 1 - Technical University of Varna, Electrical Power Engineering Department, 9010, 1 Studentska Street, Varna, Bulgaria \\ Corresponding author contact: m.yordanovaltu-varna.bg
}

\begin{abstract}
The Regulations on health and safety at work in the electrical installations of the electrical and the thermal power stations and the electric power lines and Ordinance №9 on the technical operation of the power stations and the electric power lines govern mainly the safety at work with high-voltage equipment in Bulgaria. In these normative documents the hazards of electric arcs are not a subject to a special section. National Fire Protection Association 70E Standards for electrical safety in the workplace require to assess whether there are arc-dangers, to calculate the energy released by the arc, to define the permissible arc protection boundaries, to provide adequate personal protective equipment and to label the equipment. The aim of the paper is to summarize the Bulgarian requirements connected somehow with the flash hazard and to compare the similarities, which can be found in the approaches for ensuring electrical safety with those on international standards.
\end{abstract}

Keywords: arc flash hazards, norm regulation, safety approaches

\section{$1 \quad$ Introduction}

One of the possible reasons for electrical accidents may be the development of open powerful electric arcs between the contacts of the switching devices, the short circuits or earth faults in the electrical switchboards, when replacing live fuses in the presence of current circuit breakdown, in unsafe testing of repaired equipment and products, etc. (Ушев \& Йорданова, 2003), (Анев, 1987), (Иванов, 2011). The energy, released by the arc, creates a rise in the temperature and the pressure in the near zone. That causes mechanical and thermal loading of the nearby equipment and creates potential for serious injuries. That's why to be close to an electric arc is extremely dangerous (ABB, 2009), (Pryanka \& Sarode, 2012):

- The pressure at a distance of $61 \mathrm{~cm}$ from an electric arc with a current of the order of $22 \mathrm{kA}$ can cause a force of $225 \mathrm{~kg}$ over the given person;

- The temperature can reach thousands of degrees Celsius;

- The sound level of an electric arc can reach $160 \mathrm{dBA}$ (which level is above the pain threshold).

The National Fire Protection Association (NFPA) is an international nonprofit organization for fire safety, electrical safety and construction safety. Flash hazard is ,a dangerous condition associated with the release of energy caused by an electric arc" (NFPA, 2004). That released (incidental) energy is defined as "the amount of energy impressed on a surface, a certain distance from the source, generating during an electrical arc event" (NFPA, 2004). One of the units used to measure the incident energy is calories per centimeter squared $\left(\mathrm{cal} / \mathrm{cm}^{2}\right.$. This energy is used to determine the level of the personal protective equipment (PPE) and the permissible boundaries of protection from the impact of the electric arc.

An electric arc risk analysis defines procedures that limit the possible damage to the personnel and by measuring the incidental energy to define the risk areas and the appropriate PPE level (ABB, 2009).

The aim of the paper is to summarize the Bulgarian requirements connected someway with the flash hazard, to compare the similarities in the approaches for ensuring the electrical safety with those from international standards. 


\section{International and Bulgarian norms}

The international standards dealing with the prevention of the effects from arc flash are mainly:

- NFPA 70 National Electrical Code; • NFPA 70E Standards for Electrical Safety in the Workplace;

- IEEE standard 1584-2008. Guide for Performing Arc Flash Hazard Calculations.

As a protection against the arc flash hazards it is required the following (NFPA, 2004), (NFPA, 2009), (ABB, 2009), (OSHA, 2008):

- To have an assess whether there are arc-dangers (there would be no danger if the electrical equipment is switched off);

- To calculate the energy released by the arc, if any;

- To define the permissible arc protection boundaries;

- To provide adequate personal protective equipment for staff;

- To label the equipment. Labels should indicate the minimum protection distance, the energy that can be released and the required personal protective equipment.

\subsection{Bulgarian norms}

The Regulations on health and safety at work in the electrical installations of the electrical and the thermal power stations and the electric power lines (Правилник, 2005) and Ordinance №9 (Наредба, 2004) on the technical operation of the power stations and the electric power lines govern mainly the safety at work with high-voltage equipment in Bulgaria. In these normative documents the hazards of electric arcs are not a subject to a special section.

The values for the permissible distances, that are relevant to the topic being discussed, can be found in (Правилник, 2005) and they must be observed for the following activities:

A) The voltage switch-off is regulated for the energized parts to be operated with them, as well as for those, which can be accidentally touched or can be approached at a distance less than the indicated in Table 1, (Правилник, 2005);

B) Inspections in the high voltage electrical systems (over $1000 \mathrm{~V}$ up to $35 \mathrm{kV}$ ) by one person;

C) Painting the poles of overhead power lines without switching off the voltage;

D) Working on one switched-off triple line of overhead power line with two triple line suspended on the pole when the second triple is under voltage;

E) Work with lifting equipment;

F) Overhead cable lines and air lines with insulated conductors under high voltage.

Table 1. Minimum distances to ensure safety in various activities with high voltage equipment and power lines (Правилник, 2005).

\begin{tabular}{|c|c|c|c|c|c|c|}
\hline Voltage & $\begin{array}{l}\text { Up to } \\
1 \mathrm{kV}\end{array}$ & $\begin{array}{r}\text { Over } 1 \mathrm{kV} \\
\text { up to } 20 \mathrm{kV}\end{array}$ & $\begin{array}{l}\text { Up to } \\
35 \mathrm{kV}\end{array}$ & $\begin{array}{l}\text { Over } 35 \mathrm{kV} \text { up } \\
\text { to } 110 \mathrm{kV}\end{array}$ & $220 \mathrm{kV}$ & $400 \mathrm{kV}$ \\
\hline 1.Activity A), $\mathrm{m}$ & \multicolumn{3}{|c|}{1} & 1.5 & 2.5 & 4.5 \\
\hline $\begin{array}{l}\text { 2.Distance for placing temporary bar- } \\
\text { riers, } \mathrm{m}\end{array}$ & 0.1 & 0.35 & 0.6 & 1.5 & 2 & 3.5 \\
\hline 3.Activity B), $\mathrm{m}$ & \multicolumn{3}{|c|}{ From 2,5 to 2,75} & - & - & - \\
\hline 4.Activity C), $\mathrm{m}$ & \multirow{2}{*}{\multicolumn{3}{|c|}{$\frac{2}{3}$}} & & 2.5 & 4.5 \\
\hline 5.Activity D), $\mathrm{m}$ & & & & 4 & 6 & 9 \\
\hline 6.1. Activity E, Switchgear Yard, m & \multicolumn{3}{|c|}{1} & 1.5 & 2.5 & 4.5 \\
\hline 6.2.Activity E Overhead Power Lines, $m$ & 1,5 & 2 & - & 4 & 5 & 8 \\
\hline 7. Activity F, m & \multicolumn{3}{|c|}{0,6 to $1 \mathrm{~m}$} & - & - & - \\
\hline
\end{tabular}

\subsection{Safety approaches according to NFPA 70 (NFPA, 2004), (see Fig.1)}

Flash Protection Boundary (FPB), Dc - „An approach limit at a distance from exposed live parts within which a person could receive a second degree burn if an electrical arc flash were to occur."

Limited Approach Boundary (LAB) - „An approach limit at a distance from exposed live parts within which a shock hazard exists.“ 
Restricted Approach Boundary (RAB) - „An approach limit at a distance from exposed live parts within which there is an increased risk of shock, due to electrical arc over combined with inadvertent movement, for personnel working in close proximity to the live part."

Prohibited Approach Boundary (PAB) - „An approach limit at a distance from exposed live parts within which work is considered the same as making contact with the live part."

Those boundaries define the following spaces (see Fig.1):

- $\quad$ Limited space (LS) is the zone of the final access, which is between LAB and RAB.

- $\quad$ Restricted space (RS) is a restraint zone between RAB и PAB.

- Prohibited space (PS) is a forbidden zone between PAB and any point of the exposed live parts.

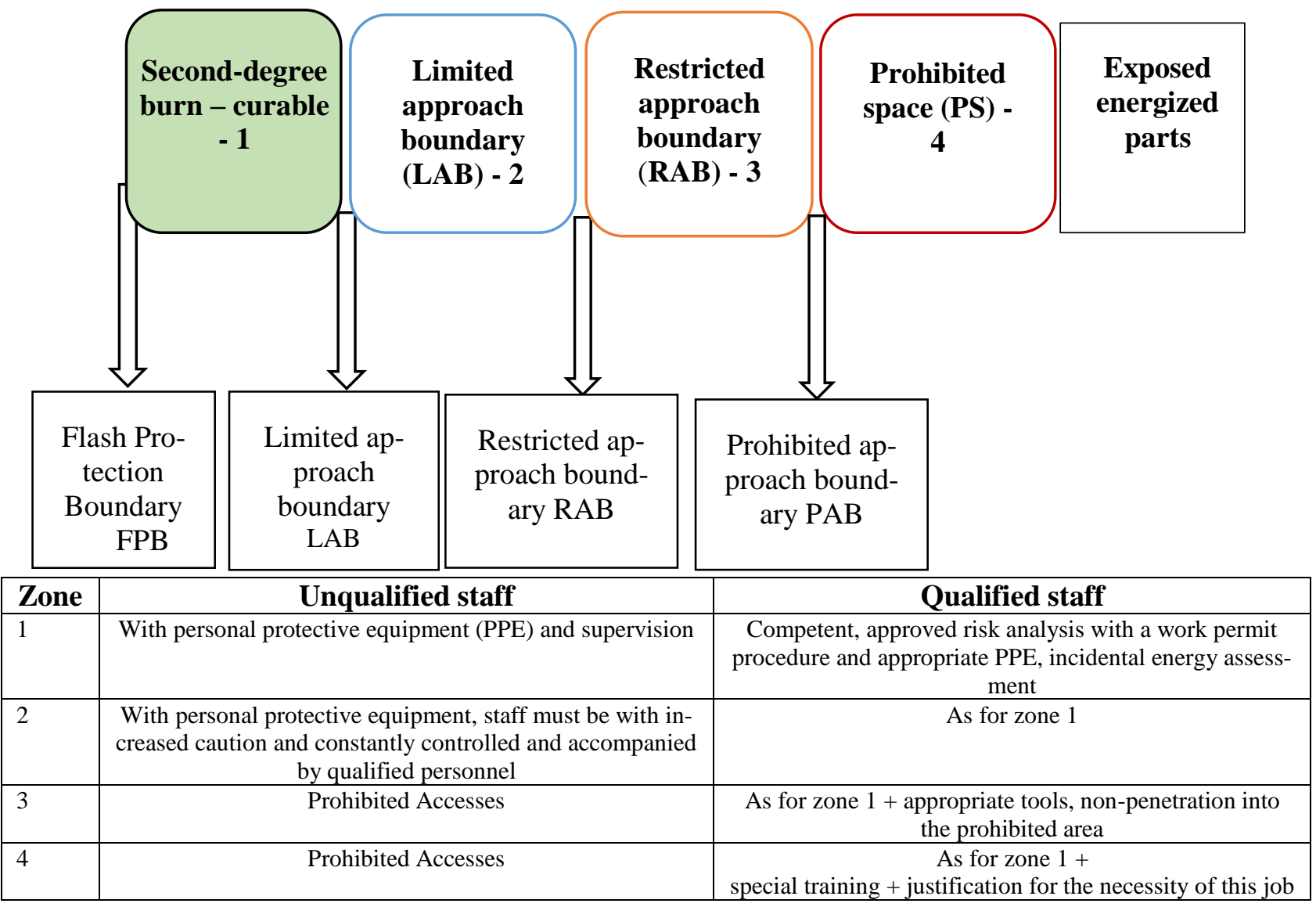

Fig. 1. Boundaries and areas to ensure safety against arc flash risk in accordance with NFPA 70 E (ABB, 2009), (NFPA, 2004).

\section{The safety measures are $(\mathrm{ABB}, 2009)$ :}

1. Crossing FPB only with a suitable Personal Protective Equipment (PPE)

2. Crossing LAB only by qualified personnel;

3. Crossing RAB, the qualified personnel must:

- have a work permit approved by an authorized person;

- wear personal protective equipment in accordance with the voltage;

- be sure that his or her body or part of it will not enter the forbidden PAB area;

- minimize the risk of unintended movement by keeping the body out of the prohibited zone as much as possible and using only the protected parts of the body.

4. When crossing the PAB, the qualified personnel must:

- have a proper training for work with live parts;

- have a documented and approved plan that certifies the need for work so close to live parts;

- do a risk analysis and an appropriate PPE must be used. 
5. The following data is required to perform an electric arc risk analysis:

- Short-circuit power at the point of supplying or short-circuit current and voltage;

- Nominal power of each potential transformer;

- Single line diagram;

- Cable size and length;

- Protective equipment.

Then, it can be calculated the following:

1. The short-circuit currents;

2. The hazard area (distance $\mathrm{D}_{c}$ ) and the energy released by the arc (the formulas are given in NFPA, 2004 and the values depend on the short-circuit tripping time);

3. The risk category can be defined to determine the minimum requirements for the personal protective equipment.

The NFPA 70E defines six categories for the risk of electric arc danger and the PPE requirements.

The maximum incidental energy causing healed burns is $1.2 \mathrm{cal} / \mathrm{cm}^{2}\left(5 \mathrm{~J} / \mathrm{cm}^{2}\right)$. As a result, the used PPE reduces the incident energy on the human body to a level less than this value.

After the calculations, the appropriate level of personal protective equipment can be determined.

The Document NFPA $70 \mathrm{E}$ defines the following area sizes around the possible source of electric arc according to the voltage of the current-carrying parts (See Table 2).

Table 2. Sizes of areas around the possible source of electric arc (NFPA, 2015).

\begin{tabular}{|c|c|c|c|c|}
\hline Voltage & \multicolumn{2}{|c|}{ Limited Approach Boundary } & \multicolumn{1}{c|}{$\begin{array}{c}\text { Restricted Approach } \\
\text { Boundary }\end{array}$} & $\begin{array}{c}\text { Prohibited Approach } \\
\text { Boundary }\end{array}$ \\
& $\begin{array}{l}\text { Movable } \\
\text { Exposed } \\
\text { Parts }\end{array}$ & $\begin{array}{c}\text { Fixed } \\
\text { Pxposed } \\
\text { Parts }\end{array}$ & Avoiding contact & Avoiding contact \\
\hline $50-300 \mathrm{~V}$ & $3 \mathrm{~m}$ & $1 \mathrm{~m}$ & $0.3 \mathrm{~m}$ & $0,025 \mathrm{~m}$ \\
\hline $301-750 \mathrm{~V}$ & $3 \mathrm{~m}$ & $1 \mathrm{~m}$ & $0.7 \mathrm{~m}$ & $0.2 \mathrm{~m}$ \\
\hline $751 \mathrm{~V}-15 \mathrm{kV}$ & $3.0 \mathrm{~m}$ & $1.5 \mathrm{~m}$ & $0.8 \mathrm{~m}$ & $0.3 \mathrm{~m}$ \\
\hline $15.1-36 \mathrm{kV}$ & $3.0 \mathrm{~m}$ & $1.8 \mathrm{~m}$ & $0.8 \mathrm{~m}$ & $0.6 \mathrm{~m}$ \\
\hline $36.1-46 \mathrm{kV}$ & $3.0 \mathrm{~m}$ & $2.5 \mathrm{~m}$ & $1.0 \mathrm{~m}$ & $0.8 \mathrm{~m}$ \\
\hline $46.1-72.5 \mathrm{kV}$ & $3.0 \mathrm{~m}$ & $2.5 \mathrm{~m}$ & $1.0 \mathrm{~m}$ & $1.0 \mathrm{~m}$ \\
\hline $72.6-121 \mathrm{kV}$ & $3.3 \mathrm{~m}$ & $2.5 \mathrm{~m}$ & $1.2 \mathrm{~m}$ & 1.5 \\
\hline $138-145 \mathrm{kV}$ & $3.4 \mathrm{~m}$ & $3.0 \mathrm{~m}$ & $1.3 \mathrm{~m}$ & $2.6 \mathrm{~m}$ \\
\hline $161-169 \mathrm{kV}$ & $3.6 \mathrm{~m}$ & $3.6 \mathrm{~m}$ & $1.6 \mathrm{~m}$ & $3.5 \mathrm{~m}$ \\
\hline $230-242 \mathrm{kV}$ & $4.0 \mathrm{~m}$ & $4.0 \mathrm{~m}$ & $2.8 \mathrm{~m}$ & $3.6 \mathrm{~m}$ \\
\hline $345-363 \mathrm{kV}$ & $4.7 \mathrm{~m}$ & $4.7 \mathrm{~m}$ & $5.8 \mathrm{~m}$ & \\
\hline $500-550 \mathrm{kV}$ & $5.8 \mathrm{~m}$ & & \\
\hline
\end{tabular}

In summary, the following range of the safety distances according to the Bulgarian regulations, the range of limited approach boundaries and restricted approach boundaries can be derived depending on the voltage given in Table 1 and Table 2.

Table 3. The range of the safety distances, the limited approach boundaries and the restricted approach boundaries.

\begin{tabular}{|c|c|c|c|c|c|c|}
\hline Voltage & $\begin{array}{c}\text { Up to } \\
\mathbf{1 ~ k V}\end{array}$ & $\begin{array}{c}\text { Above } \\
\mathbf{1 ~ k V ~ t o} \\
\mathbf{2 0 ~ k V}\end{array}$ & $\begin{array}{c}\text { Up to 35 } \\
\mathbf{k V}\end{array}$ & $\begin{array}{c}\text { Above } \\
\mathbf{3 5 ~ k V ~ t o ~} \\
\mathbf{1 1 0} \mathbf{~ k V}\end{array}$ & $\mathbf{2 2 0 ~ k V}$ & $\mathbf{4 0 0} \mathbf{~ k V}$ \\
\hline $\begin{array}{c}\text { Safety distances } \\
\text { (Правилник, 2005) } \\
\text { Table 1, m }\end{array}$ & $1 \div 1,5$ & $1 \div 3$ & $1 \div 3$ & $1.5 \div 4$ & $2.5 \div 6$ & $4.5 \div 9$ \\
\hline $\begin{array}{c}\text { Limited Approach Boundary } \\
\text { (NFPA, 2015) } \\
\text { Table 2, m }\end{array}$ & $1 \div 3$ & $1.8 \div 3$ & $1.8 \div 3$ & $2.5 \div 3.3$ & 4 & $4.7 \div 5.8$ \\
\hline $\begin{array}{c}\text { Restricted Approach Bound- } \\
\text { ary (NFPA, 2015) } \\
\text { Table 2, m }\end{array}$ & $0.3 \div 0.7$ & $0.7 \div 0.8$ & 0.8 & $0.8 \div 1.0$ & 1.6 & $2.8 \div 3.6$ \\
\hline
\end{tabular}




\section{Conclusion}

1. The Bulgarian regulations do not have special sections for protection against electric arc risk, but similarities can be found in some approaches for ensuring electrical safety with these from the of international standards. They are given in Table 4.

Table 4. The similarities in some approaches for ensuring electrical safety.

\begin{tabular}{|c|c|}
\hline NFPA 70 E standards & Bulgarian regulations \\
\hline $\begin{array}{l}\text { Existence of a work plan approved by an authorized per- } \\
\text { son }\end{array}$ & Existence of a work permit or an oral order \\
\hline Personal protective equipment according to the voltage & Presence of the basic protective equipment \\
\hline $\begin{array}{c}\text { Do not allow the body or part of the body to enter the } \\
\text { prohibited area }\end{array}$ & $\begin{array}{l}\text { Obligation to observe the allowable distances according to } \\
\text { Table } 1\end{array}$ \\
\hline Existence of training for work on live parts & $\begin{array}{l}\text { The requirement for qualification on safety and health at } \\
\text { work, training and working together with a qualified person }\end{array}$ \\
\hline $\begin{array}{l}\text { Presence of a documented and approved plan, certifying } \\
\text { the necessity for work so close to parts under voltage }\end{array}$ & Existence of a work permit or an oral order \\
\hline Risk analysis & $\begin{array}{l}\text { Obligation of the issuing or commissioning authority of the } \\
\text { work permit/ order to assess how the job can be done safely }\end{array}$ \\
\hline
\end{tabular}

2. From the comparison between the safety distances, the limited approach boundaries and the restricted approach boundaries (see Table 3) can be seen that the values of the safety distances according Bulgarian regulations are between the values of the limited approach boundaries and the restricted approach boundaries. There is no difference between the safety values for the two voltage ranges - up to $20 \mathrm{kV}$ and up to $35 \mathrm{kV}$, that need to be considered in case of future changes in the regulations.

3. Nevertheless, when carrying out specific work in high voltage electrical systems, the requirements of the NFPA 70E international normative document may be applied in cases where higher safety requirements are needed. That requirement may be included in the work safety instruction.

\section{References}

ABB Low Voltage Circuit Breakers. Arc Flash Hazards. (2009) ABB Inc. Low Voltage Control Products \& Systems. Retrieved from https://library.e.abb.com/public/2b5f3d9051ccdd76852576ac006dc16b/1SXU210204G0201.pdf (last visited 27.10.2018).

National Fire Protection Association. (2004). NFPA 70E Standard for Electrical Safety in the Workplace. (Ed. 2004).

National Fire Protection Association. (2015). NFPA 70E Standard for Electrical Safety in the Workplace. (Ed. 2015). Retrieved from http://safety.ep.wisc.edu/wp-uploads/2017/03/36.-2015NFPA-70E-Copy.pdf (last visited 27.10.2018).

OSHA Occupational Safety and Health Administration US Department of Labor. Electrical Safety in the Workplace Manual. (2008). Available from https://www.osha.gov/dte/grant_materials/fy09/sh-18794-09/electrical_safety_manual.pdf (last visited 27.10.2018).

Pryanka, K. K., \& Sarode, U. B. (2012). Practical Approach for Arc Flash Hazard Assessment. International Journal on Advanced Electrical and Electronics Engineering, (IJAEEE), ISSN (Print): 2278-8948, Volume-1, Issue-1, 2012, 33-39. http://www.irdindia.in/journal_ijaeee/pdf/vol1_iss1/7.pdf 
Анев, Г. (1987) Вредни действия на електричеството и защита от тях. Техника, София. (in Bulgarian).

Иванов, И., Петров, П., Велев, Г.\& Витков, Н. (2011). Техническа безопасност. Технически университет, София. ISBN 978-954-9518-66-5, (in Bulgarian).

Наредба №9 за техническа експлоатация на електрически централи и мрежи, 2004. http://www.gli.government.bg/page.php?c=34\&page=8. (in Bulgarian, last visited 27.10.2018).

Правилник по безопасност и здраве при работа в електрически уредби на електрически и топлофикационни централи и по електрически мрежи, 2005. http://www.gli.government.bg/page.php?c=33. (in Bulgarian, last visited 27.10.2018).

Ушев, Г. \& Йорданова, М. (2003). Техническа безопасност. Записки - част 2, Здравословни и безопасни условия на труд. Технически университет, Варна. ISBN 954-424-142-6 (in Bulgarian). 